\title{
SISTEM VERIFIKASI TANDA TANGAN OFF-LINE BERDASAR CIRI HISTOGRAM OF ORIENTED GRADIENT (HOG) DAN HISTOGRAM OF CURVATURE (HoC)
}

\author{
Agus Wahyu Widodo', Agus Harjoko² \\ ${ }^{1}$ Program Studi Ilmu Komputer, Fakultas Ilmu Komputer, Universitas Brawijaya, Malang \\ 2 Jurusan Ilmu Komputer dan Elektronika, FMIPA UGM, Yogyakarta \\ Email: ${ }^{1}$ a_wahyu_w @ub.ac.id, ${ }^{2}$ aharjoko@ugm.ac.id
}

(Naskah masuk: 29 Januari 2015, diterima untuk diterbitkan: 17 Februari 2015)

\begin{abstract}
Abstrak
Tanda tangan dengan sifat uniknya merupakan salah satu dari sekian banyak atribut personal yang diterima secara luas untuk verifikasi indentitas seseorang, alat pembuktian kepemilikan berbagai transaksi atau dokumen di dalam masyarakat. Keberhasilan penggunaan ciri gradien dan curvature dalam bidang-bidang penelitian pengenalan pola dan bahwa tanda tangan dapat dikatakan merupakan hasil tulisan tangan yang tersusun atas beragam garis dan lengkungan (curve) yang memiliki arah atau orientasi merupakan alasan bahwa kedua ciri tersebut digunakan sebagai metoda verifikasi tanda tangan offline di penelitian ini. Berbagai implementasi dari pre-processing, ekstraksi dan representasi ciri, dan pembelajaran SVM serta usaha perbaikan yang telah dilakukan dalam penelitian ini menunjukkan hasil bahwa ciri HOG dan HoC mampu dimanfaatkan dalam proses verifikasi tanda tangan secara offline. Pada basis data GPDS960Signature, HOG dan HoC yang dihitung pada ukuran sel 30 x 30 piksel memberikan dengan nilai \%FRR terbaik 26,90 dan \%FAR 37,56. Sedangkan pada basis data FUM-PHSDB, HOG dn HoC yang dihitung pada ukuran 60 x 60 piksel memberikan nilai \%FRR terbaik 4 dan \%FAR 57.
\end{abstract}

Kata kunci: verifikasi tanda tangan, curvature, orientation, gradient, histogram of curvature (HoC), histogram of oriented gradient (HOG)

\begin{abstract}
Signature with unique properties is one of the many personal attributes that are widely accepted to verify a person's identity, proof of ownership transactions instrument or document in the community. The successful use of gradient and curvature feature in the research fields of pattern recognition is the reason that both of these features are used as an offline signature verification method in this study. Various implementations of preprocessing, feature extraction and representation, and SVM learning has been done in the study showed results that HOG and HoC feature can be utilized in the process of offline signature verification. HOG and HOC calculated on a combination of two different cell sizes at a time. Improvement effort has been made and showed the expected results, although of little value. HOG and HOC calculated on a such cell sizes at a time. In database GPDS960Signature, best cell size is in 30 with the value 26.90\% FRR and FAR 37.56\%. While the database FUM-PHSDB, the best cell size is 60 with a value of $4 \%$ FRR and FAR 57\%.
\end{abstract}

Keywords: signature verification, curvature, orientation, gradient, a histogram of curvature (HOC), a histogram of oriented gradient (HOG)

\section{PENDAHULUAN}

Tanda tangan dengan sifat uniknya merupakan salah satu dari sekian banyak atribut personal yang diterima secara luas untuk verifikasi indentitas seseorang, alat pembuktian kepemilikan berbagai transaksi atau dokumen di dalam masyarakat. Sampai saat ini, untuk keperluan legalitas, hampir semua dokumen seperti cek bank, paspor perjalanan dan sertifikat akademik perlu diotorisasi dengan menggunakan tanda tangan. Karena begitu pentingnya arti tanda tangan, secara hukum dinyatakan pula bahwa fungsi tanda tangan adalah untuk memberikan ciri atau mengindividualisir suatu akta (Wibowo, 2001).
Terdapat perbedaan tujuan antara sistem verifikasi dan identifikasi atau pengenalan tanda tangan. Verifikasi bertujuan untuk memutuskan apakah suatu tanda tangan merupakan milik atau termasuk dalam suatu kelas, dalam hal ini adalah penandatangan, ataukah bukan. Sedangkan pengenalan atau identifikasi bertujuan untuk memutuskan dari sejumlah klas tertentu manakah penandatangan dapat masuk di dalamnya. Oleh karena itu dalam penerapannya sistem verifikasi dapat menggunakan salah satu metoda klasifikasi yang umum digunakan dalam bidang pengenalan pola atau pattern recognition.

Berdasarkan prosesnya sistem verifikasi tanda tangan otomatis dapat dikategorikan menjadi 2 jenis 
yaitu on-line dan off-line. Sistem verifikasi on-line mengacu pada suatu proses yang mana penandatangan menggunakan pena khusus atau stylus untuk membuat tanda tangannya. Sedangkan sistem verifikasi off-line hanya bekerja dengan pemrosesan citra tandatangan yang dapat diperoleh dari suatu mesin pemindai atau kamera digital.

Verifikasi secara off-line memiliki beberapa keuntungan dibandingkan verifikasi secara on-line (Nguyen et al., 2010). Pertama, verifikasi jenis ini telah diterima secara luas di dalam masyarakat. Kedua, prosesnya relatif lebih sederhana karena tidak memerlukan peralatan khusus. Ketiga, masih terdapatnya sejumlah besar formulir check perbankan, formulir kepemilikian kartu kredit, atau dokumen-dokumen resmi yang masih ditanda tangani secara manual setiap harinya. Atas dasar ketiga alasan tersebut verifikasi secara off-line dipertimbangkan memiliki potensi untuk diteliti dan dikembangkan. Beberapa upaya peningkatan akurasi dan kecepatan verifikasi tanda tangan secara off-line telah dilakukan dalam banyak penelitian (Ismail et al., 2008), (Nguyen \& Blumenstein, 2011), (Nguyen et al., 2010), (Parodi et al., 2011) (Vargas \& Ferrer, 2011), (Sigari et al., 2011) (Kiani et al., 2009) (Ferrer et al., 2012) (Pourshahabi et al., 2009) .

Dari sudut pandang pemrosesan citra berbasis ciri, ciri pada citra tanda tangan dapat dikatakan serupa dengan ciri karakter tulisan tangan. Keduanya tersusun atas beragam garis dan lengkungan (curve) yang memiliki arah atau orientasi (Cheriet et al., 2007). Orientasi atau arah goresan memainkan peran penting dalam membedakan antara berbagai karakter atau tanda tangan seorang dengan orang yang lain. Oleh karena itu dalam penelitian ini ciri orientasi dan lengkungan (curve) menjadi ciri yang akan diekstraksi dari citra tanda tangan dan digunakan dalam verifikasi tanda tangan.

Ciri Histogram of Oriented Gradient (HoG) atau histogram lokal adalah salah satu deskriptor ciri yang berbasis pada arah dan digunakan pada pengolahan citra dan computer vision. Ciri HoG dideskripsikan pertama kali oleh Dalal dan Triggs (2005) pada paper mereka bulan Juni 2005. Dalam paper tersebut algoritma HOG difokuskan pada permasalahan deteksi pejalan kaki dalam citra statis. Ekstraksi ciri HOG dilakukan dengan menghitung orientasi gradien di suatu daerah yang dilokalisasi pada citra.

Curvature atau kelengkungan merupakan ciri tingkat rendah yang umum digunakan dalam pengenalan pola. Secara intuitif, curvature merupakan laju perubahan arah tepi (Nixon \& Aguado, 2002). Laju perubahan arah tepi ini dapat mengkarakterisasi titik-titik dalam kurva; titik-titik dimana arah tepi berubah secara cepat disebut sudut atau corner, sedangkan titik-titik di mana terdapat sedikit perubahan dalam arah tepian merupakan garis lurus. Titik-titik ekstrem tersebut sangat berguna untuk deskripsi dan pencocokan bentuk, karena curvature mampu mewakili informasi yang signifikan.

Sebagai deskriptor ciri obyek, curvature telah berhasil digunakan dalam beberapa penelitian tentang pengenalan pola. Salah satunya adalah pengenalan karakter angka tulisan tangan (Fujisawa et al., 2000). Dalam penelitian ini digunakan salah metoda ekstraksi ciri curvature, yaitu Bi-Quadratic Interpolation. Metoda ini dikenakan pada citra greyscale tulisan tangan angka yang berukuran 120x80 piksel. Penerapan metoda tersebut menghasilkan akurasi pengenalan sebesar 99.37\% dengan waktu cpu sebesar 0.078 detik tiap karakternya.

Berdasarkan uraian fakta yang ada maka dalam usulan penelitian ini akan dilakukan kombinasi ciri orientasi gradien dan curvature dalam verifikasi tanda tangan secara off-line. Selanjutnya, kedua ciri ini direpresentasikan sebagai Histogram of Oriented Gradient (HOG) dan Histogram of Curvature (HoC). Algoritma yang direpresentasikan oleh Dalal dan Triggs dalam paper mereka tentang pendeteksian pejalan kaki pada citra statis akan digunakan sebagai metoda representasi ciri ke dalam bentuk HOG. Kombinasi kedua representasi ciri ini diharapkan mampu digunakan sebagai salah satu metoda dalam proses verifikasi tanda tangan secara off-line.

\section{HISTOGRAM}

Histogram merupakan suatu bentuk diagram batang yang mampu menampilkan distribusi perhitungan citra tak terurut secara spasial pada suatu daerah dan invarian relatif pada beberapa transformasi obyek dalam citra (Laptev, 2009). Cakupan daerah citra yang dikenai perhitungan akumulasi dari histogram menentukan jenis histogramnya, yaitu histogram global dan histogram lokal. Histogram global merupakan histogram yang didapatkan jika cakupan akumulasi perhitungan dilakukan pada seluruh area citra. Sedangkan histogram lokal merupakan histogram yang didapatkan jika cakupan perhitungan dilakukan pada suatu luasan tertentu citra. Cakupan daerah perhitungan histogram memberikan dampak yang besar bagi pengenalan obyek (Laptev, 2009). Histogram global tidak cocok untuk citra yang kompleks, pendekatan yang lebih baik adalah menggunakan histogram lokal karena memberikan informasi obyek yang lebih spesifik (Dalal \& Triggs, 2005).

\section{HISTOGRAM OF ORIENTED GRADIENT (HOG)}

Pemikiran utama di balik deskriptor Histogram of Oriented Gradient (HOG) adalah bahwa 
penampilan obyek dan bentuk lokal dalam sebuah citra dapat digambarkan oleh distribusi intensitas atau arah gradien tepi. Penerapan deskriptor ini dapat dicapai dengan membagi citra ke dalam daerah-daerah kecil yang saling terhubung, yang disebut sel, dan untuk setiap sel disusun histogram arah gradien atau orientasi tepi untuk tiap-tiap piksel yang berada di dalam sel. Kombinasi histogramhistogram ini kemudian menyatakan deskriptor. Sedangkan gradien pada masing-masing piksel didapatkan dengan menerapkan filter [-1 0 l 1$]$ dan [-1 0 1]T (Dalal \& Triggs, 2005).

Dasar pembentukan ciri HOG di masing-masing sel adalah proses akumulasi piksel yang memiliki orientasi yang sama. Di mana arah gradient akan dikelompokkan menjadi beberapa bagian yang disebut bin. Menurut penelitian yang dilakukan oleh Dalal, untuk mendapatkan hasil deteksi terbaik jika jumlah bin yang digunakan untuk pembagian arah minimal berjumlah 8 bin. Namun pada penelitian lain disebutkan bahwa jumlah bin sebesar 9 memberikan hasil deteksi yang lebih optimal (Kobayashi et al., 2008). Karena alasan tersebut maka dalam penelitian ini dipilih penyusun HOG juga sebesar 9 bin.

\section{EKSTRAKSI CIRI CURVATURE DENGAN METODA BI-QUADRATIC INTERPOLATION}

Curvature atau kelengkungan merupakan ciri tingkat rendah yang umum digunakan dalam pengenalan pola. Secara intuitif, curvature dapat dikatakan sebagai laju perubahan arah tepi (Nixon \& Aguado, 2002). Laju perubahan arah tepi ini dapat mengkarakterisasi titik-titik dalam kurva; titik-titik dimana arah tepi berubah secara cepat disebut sudut atau corner, sedangkan titik-titik di mana terdapat sedikit perubahan dalam arah tepian merupakan garis lurus. Titik-titik ekstrem tersebut sangat berguna untuk deskripsi dan pencocokan bentuk, karena curvature mampu mewakili informasi yang signifikan.

$\begin{array}{ccc}X_{4} & X_{3} & X_{2} \\ X_{5} & X_{0} & X_{1} \\ X_{6} & X_{7} & X_{8}\end{array}$

Gambar 1. Delapan arah ketetanggaan titik $X_{0}$ dalam perhitungan curvature

Dalam prinsip delapan arah ketetanggan dari satu piksel $X_{0}$ dari suatu citra dinyatakan susunan piksel-piksel seperti yang ditunjukkan dalam Gambar 1. Nilai piksel $X_{k}$ dinotasikan sebagai $f_{\mathrm{k}}$. Maka koefisien curvature $c$ dari $X_{0}$, dengan menggunakan metoda Bi-quadratic Interpolation, dapat dinyatakan dalam persamaan (1) (Fujisawa et al., 2000).

$$
c=-\frac{2\left(a_{10}{ }^{2} a_{02}-a_{01} a_{10} a_{11}+a_{01}{ }^{2} a_{20}\right)}{\left(a_{10}{ }^{2}+a_{01}{ }^{2}\right)^{\frac{3}{2}}}
$$

Keterangan:

$a_{10}, a_{20}, a_{01}, a_{02}$, dan $a_{11}=$ permukaan bi-quadratic yang secara berurutan dinyatakan dalam persamaan (2), (3), (4), (5) dan (6) (Fujisawa et al., 2000).

$$
\begin{gathered}
a_{10}=\left(f_{1}-f_{5}\right) / 2 \\
a_{20}=\left(f_{1}+f_{5}-2 f_{0}\right) / 2 \\
a_{01}=\left(f_{3}-f_{7}\right) / 2 \\
a_{02}=\left(f_{3}+f_{7}-2 f_{0}\right) / 2 \\
a_{11}=\left\{\left(f_{2}-f_{8}\right)-\left(f_{4}-f_{6}\right)\right\} / 4
\end{gathered}
$$

Keterangan:

$f_{k}=$ nilai piksel ke-k. Jadi kalau $f_{1}$ adalah nilai piksel ke-1, $f_{2}$ adalah nilai piksel ke-2 dan seterusnya.

\section{METODE PENELITIAN}

\subsection{Gambaran Umum Sistem}

Untuk dapat digunakan, 2 bagian yang membentuk sistem verifikasi tanda tangan offline dalam penelitian ini, yaitu development dan application, harus diselesaikan secara berurutan. Bagian yang pertama adalah development, yaitu bagian untuk membentuk basis data ciri dan fungsi pemisah SVM yang dihasilkan dari pembelajaran SVM. Setelah fungsi pemisah SVM terbentuk, bagian kedua yaitu application dapat dilakukan. Application merupakan bagian yang bertujuan melakukan proses verifikasi dengan menggunakan fungsi pemisah yang diperoleh dalam tahap development. Ilustrasi hubungan antar bagian secara umum dalam bagian development maupun application ditunjukkan oleh diagram blok dalam Gambar 2.

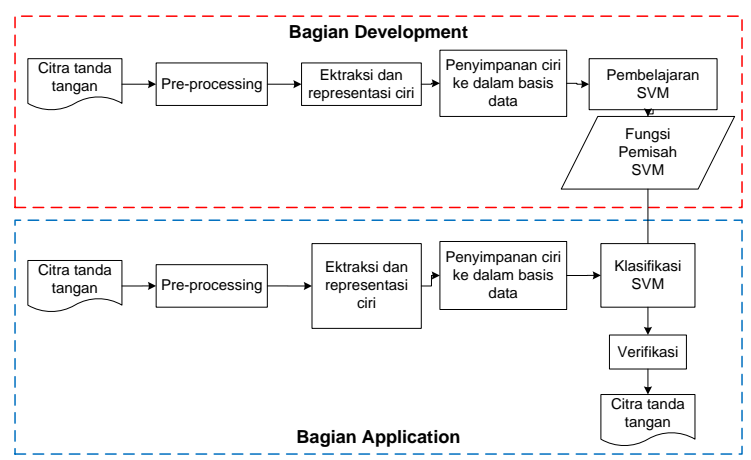

Gambar 2. Diagram blok sistem secara umum

Tahap preprocessing yang merupakan tahap awal dalam bagian development. Akuisisi dalam tahap ini dilakukan dengan melakukan pemindaian tanda tangan dari dokumen tercetak. Selanjutnya binerisasi, denoising dan normalisasi dilakukan pada 
citra tanda tangan yang telah diakuisisi sehingga didapatkan bentuk yang dapat diekstraksi cirinya.

Ciri gradient dan curvature yang disusun dalam bentuk histogram merupakan hasil yang didapatkan dari tahap ekstraksi dan representasi ciri (feature extraction and representation). Sebelum histogram disusun, perhitungan gradient maupun curvature dilakukan pada masing-masing bagian citra yang disebut blok citra. Pada masing-masing ini pula kedua histogram dibentuk. Akhirnya, ciri citra akan diwakili oleh kedua histogram, HOG dan HoC, yang didapatkan dari masing-masing blok tersebut.

Semua data ciri citra tanda tangan yang digunakan untuk melatih SVM harus disimpan ke dalam sistem basis data. Tanda tangan dari seseorang dapat diwakili oleh lebih dari satu citra sedangkan masing-masing citra akan membentuk lebih dari satu HOG maupun HoC. Sehingga ciri tanda tangan seseorang akan tersimpan dalam banyak baris data pada sistem basis yang digunakan.

Berdasarkan data ciri yang telah disimpan pembelajaran SVM akan dilakukan. Dalam pembelajarannya, SVM memerlukan data masukan berupa jumlah klas (yang sesuai dengan jumlah orang yang akan diverifikasi tanda tangannya) dan data ciri yang telah ditandai dengan label klas/orang yang memiliki citra tersebut. Urutan dan jumlah label ini harus sesuai dengan jumlah klas/orang yang bertanda tangan. Hasil dari proses pembelajaran ini adalah sekumpulan data yang disebut support vector yang membentuk fungsi pemisah, yang memisahkan ciri masing-masing klas masukan. Selanjutnya, fungsi pemisah ini disimpan dalam bentuk file untuk digunakan dalam proses application.

Bagian utama ke-2 adalah application. Dua tahap awal dalam bagian ini sama dengan tahapan di dalam bagian development, yaitu tahap preprocessing, ekstraksi dan representasi ciri, dan tahap penyimpanan ciri ke dalam basis data. Setelah ciri citra tanda tangan didapatkan, ciri ini dapat diklasifikasi dengan menggunakan fungsi pemisah SVM yang telah disimpan. Sedangkan proses verifikasi selanjutnya merupakan proses membandingkan label klas hasil klasifikasi SVM dengan label klas yang dimiliki oleh citra yang diklasifikasi. Jika hasil klasifikasi sama dengan label klas yang ada maka dapat dikatakan verifikasi berhasil dan sebaliknya jika tidak sama maka dapat dikatakan verifikasi gagal.

\subsection{Bahan penelitian}

Dalam penelitian ini digunakan citra tanda tangan yang diperoleh dari dua sumber data yang tersedia dan telah digunakan sebagai bahan penelitian serupa. Penjelasan singkat dari kedua sumber data tersebut adalah sebagai berikut:

1. Sumber data pertama adalah basis data GPDS960GRAYSignature CORPUS yang dibuat oleh Universidad de Las Palmas, Spanyol (Ferrer et al., 2012). Basis data ini menyediakan citra tanda tangan dari 960 orang yang berbeda. Dari masing-masing orang tersebut telah diambil sebanyak 24 citra tanda tangan asli dan kurang lebih 30 citra tanda tangan tiruan. Namun, dari 960 orang yang disediakan hanya akan digunakan 500 orang, yang dipilih secara berurutan, sebagai bahan penelitian, baik sebagai data latih maupun sebagai data uji.

2. Sumber data kedua adalah Persian Signature Database (FUM-PHSDB), merupakan basis data contoh tanda tangan yang dilakukan oleh orang Iran/Persia (Anon., n.d.). Tersusun atas 20 kelas/penanda tangan. Terdapat 20 citra tanda tangan asli (genuine) dan 10 citra tanda tangan pada masing-masing kelas. Jadi total citra tanda tangan asli adalah $20 \times 20=400$ citra dan total citra tanda tangan tiruan adalah $20 \mathrm{x}$ $10=200$ citra. Seluruh citra tanda tangan tiruan dibuat oleh orang yang memiliki kemampuan untuk meniru sehingga tanda tangan yang dihasilkan memiliki kemiripan dengan tanda tangan asli. Tanda tangan palsu seperti ini sering disebut skilled forgery atau expert forgery (Sigari et al., 2011).

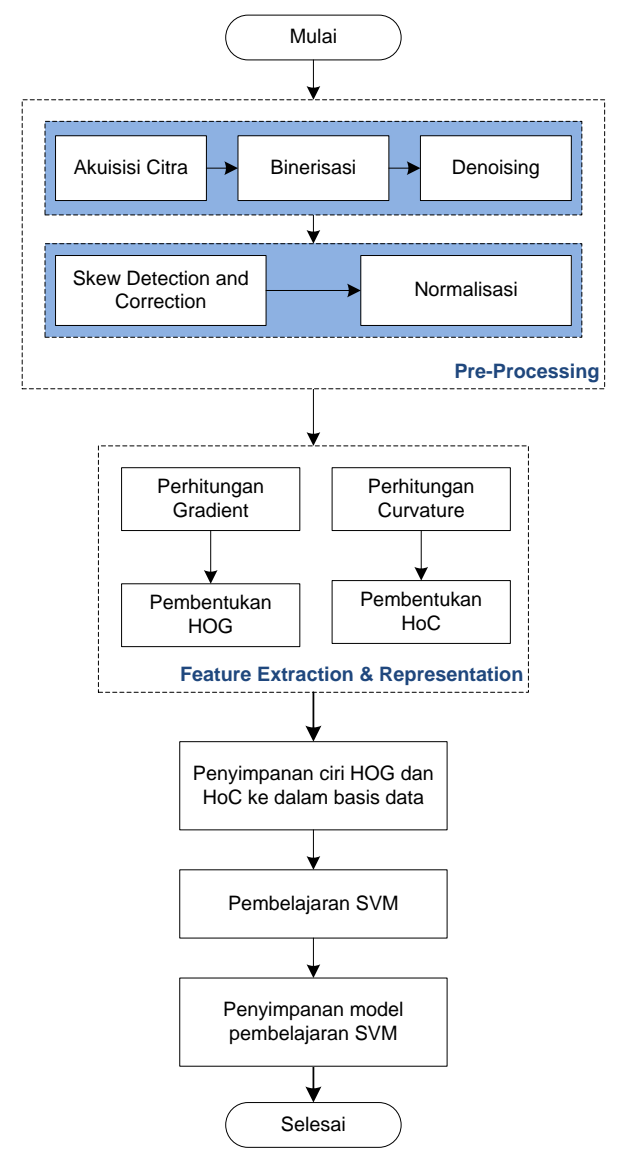

Gambar 3. Diagram alur dalam bagian development

\subsection{Alur Bagian Development}

Bagian development merupakan rangkaian tahapan pengolahan data ciri citra tanda tangan untuk membentuk model pembelajaran, dalam hal ini adalah fungsi pemisah SVM. Alur tahapan yang 
membentuk bagian development dijelaskan pada bagian berikut dan diilustrasikan dalam bentuk diagram alur yang ditunjukkan oleh Gambar 3.

\subsubsection{Pre-processing}

Tahapan pre-processing merupakan serangkaian proses yang dapat mengubah citra tanda tangan ke dalam bentuk yang dapat diekstraksi cirinya.

1. Akuisisi citra latih

Citra latih bisa didapatkan dengan melakukan digitalisasi dokumen tanda tangan asli menggunakan sebuah mesin pemindai. Masing-masing citra dipindai dalam bentuk greyscale dan dipotong dengan menggunakan perangkat lunak pemroses citra digital. Karena ciri warna bukan menjadi topik penelitian ini maka bentuk citra greyscale cukup memenuhi kebutuhan untuk proses berikutnya.

2. Denoising

Derau atau noise yang timbul pada proses pemindaian dokumen dapat dihilangkan dengan mengaplikasikan filter median (Sonka et al., 2008). Proses ini disebut dengan denoising.

3. Binerisasi

Citra greyscale diubah ke dalam bentuk citra biner dengan menggunakan metoda thresholding Otsu (Gonzales \& Woods, 2008).

4. Skew Detection and Correction

Selama proses pemindaian dokumen, seluruh dokumen atau sebagian darinya dapat diumpankan per halaman atau secara bertumpuk melalui document feeder yang terpasang pada mesin pemindai. Cara pengumpanan dokumen seperti ini sering menyebabkan kemiringan atau skew pada citra digital yang dihasilkannya. Efek visual ini muncul sebagai kemiringan baris obyek terhadap sumbu $\mathrm{x}$, dan terutama menyangkut orientasinya (Cheriet et al., 2007). Dalam banyak kasus efek ini tidak disengaja, dan harus dihilangkan karena secara dramatis mengurangi keakuratan dari proses berikutnya. Oleh karena itu dalam tahap preprocessing ini diperlukan penerapan skew detection and correction untuk mendeteksi dan memperbaiki efek visual skew atau kemiringan dokumen. Dalam penelitian ini digunakan Transformasi Hough untuk mendeteksi skew (Narappanawar et al., 2011) sedangkan untuk memperbaiki skew digunakan transformasi citra yang disediakan oleh .NET framework.

5. Normalisasi

Normalisasi diperlukan untuk mengatur ketebalan garis pembentuk obyek, ukuran, posisi, dan bentuk gambar obyek, sehingga dapat mengurangi variasi bentuk antara gambar dari kelas yang sama (Cheriet et al., 2007). Untuk mengurangi variasi perbedaan ketebalan pena yang digunakan penandatangan dalam satu kelas, digunakan proses penipisan atau thinning pada citra. Dalam proses thinning garis-garis pembentuk citra tanda tangan ditipiskan sehingga mencapai 1 piksel saja. Algoritma thinning yang digunakan adalah Zhang Suen.
Sebelum suatu citra dikenakan normalisasi ukuran perlu dipastikan bahwa obyek gambar tanda tangan memenuhi luasan citra. Cara ini dilakukan dengan melakukan pemotongan atau cropping terhadap daerah citra yang melewati batas yang dibentuk oleh piksel-piksel terluar obyek tanda tangan. Langkah selanjutnya adalah normalisasi ukuran yang berfungsi untuk meminimalkan variasi ukuran citra tanda tangan yang dihasilkan oleh penulis yang sama. Normalisasi yang digunakan merupakan normalisasi linear di mana rasio perbandingan antara lebar dan tinggi citra terhadap ukuran yang telah ditentukan (standar) adalah sebanding. Proses terakhir dalam tahap ini adalah melakukan penambahan ukuran pada masing-masing sisi citra sebesar $\mathrm{n}$ piksel. Di mana nilai $n$ tergantung dari ukuran filter yang digunakan dalam tahap ekstraksi ciri gradien. Hal ini dimaksudkan untuk menghilangkan efek tepi atau edge effect yang muncul saat penerapan mask atau filter dalam tahapan ekstraksi ciri gradien (Acharya \& Ray, 2005).

\subsubsection{Feature extraction and Representation}

1. Perhitungan Gradien dan Curvature

Gradien pada masing-masing piksel didapatkan dengan menerapkan filter $\left[\begin{array}{lll}-1 & 0 & 1\end{array}\right]$ dan $\left[\begin{array}{ccc}-1 & 0 & 1\end{array}\right]^{\mathrm{T}}$ (Dalal \& Triggs, 2005). Sedangkan Curvature didapatkan dengan menerapkan metode BiQuadratic Interpolation pada masing-masing piksel (Fujisawa et al., 2000).

2. Pembentukan HOG dan HoC

HOG dibentuk secara lokal pada tiap area tertentu di dalam citra yang disebut cell. Suatu cell ini dapat dibentuk dari sejumlah piksel berukuran $\mathrm{m}$ x m. Arah gradien dinyatakan dalam kelompok arah yang disebut bin yang membagi arah $0-360^{\circ}$ menjadi sembilan (Dalal \& Triggs, 2005). Pada masingmasing cell tiap piksel akan diakumulasi dalam jangkauan arah bin yang sama.

HoC juga dibentuk dengan cara yang serupa dengan pembentukan HOG, namun berbeda dalam pengelompokan bin-nya. Untuk membentuk HoC, bin merupakan kuantifikasi nilai curvature $c$ oleh suatu nilai threshold $t$ ke dalam 3 tingkat, yaitu: ( $c$ $\leq t)$, $(-t<c<t)$, dan $(t \leq c)$, di mana besaran nilai $\mathrm{t}$ adalah 0,15 (Fujisawa et al., 2000).

\subsubsection{Penyimpanan ciri HOG dan HoC ke dalam basis data}

Semua ciri, baik HOG dan HoC, yang telah diektraksi dari masing-masing citra latih perlu disimpan ke dalam basis data untuk kemudian diproses oleh SVM. Ciri HOG dan HoC disimpan dalam bentuk tabel-tabel yang saling berelasi.

\subsubsection{Pembelajaran SVM}

Pembelajaran atau learning SVM dilakukan dengan menggunakan seluruh data ciri citra latih yang telah tersimpan dalam basis data. Implementasinya, SVM untuk klas $\omega_{i}$ (penulis ke-i) 
diajari dengan keseluruhan ciri data latih (yang berupa HOG dan HoC) dari $\omega_{i}$ untuk membentuk fungsi keputusan $f_{i}(\mathbf{x})$ (Cheriet et al., 2007). Selanjutnya fungsi keputusan yang dihasilkan disimpan ke dalam basis data yang untuk selanjutnya akan dimanfaatkan pada proses verifikasi atau klasifikasi dengan SVM.

\subsection{Alur Bagian Application}

Bagian application merupakan tahap yang digunakan untuk melakukan verifikasi tanda tangan berdasar fungsi pemisah SVM yang telah terbentuk dalam bagian development. Pada tahap preprocessing dan feature extraction and representation memiliki kesamaan dengan yang ada pada bagian development. Perbedaaanya terletak pada citra yang diproses. Pada bagian application, citra yang diproses merupakan citra yang akan diuji atau diverifikasi. Tahapan berikutnya dalam bagian application adalah klasifikasi SVM dan verifikasi. Alur bagian application ditunjukkan dalam Gambar 4.

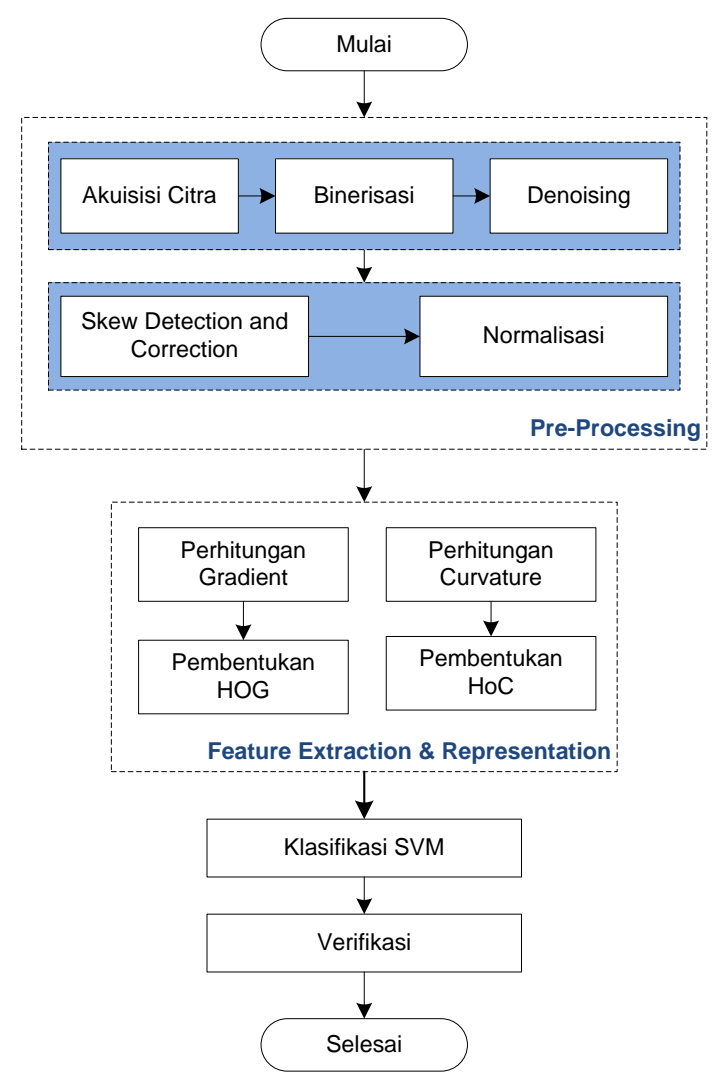

Gambar 4. Diagram alur bagian application

\section{Klasifikasi SVM}

Dengan menggunakan fungsi pemisah yang telah terbentuk dalam bagian development proses klasifikasi SVM dapat dilakukan. Proses klasifikasi dilakukan dengan memasukkan data ciri ke dalam fungsi pemisah. Hasil dari proses ini merupakan klas dari citra tanda tangan yang ingin diverifikasi.

2. Verifikasi
Proses verifikasi dilakukan dengan membandingkan klas yang dihasilkan oleh klasifikasi SVM dengan pengenal atau label penulis. Verifikasi dikatakan benar jika antara klas hasil klasfikasi SVM adalah sama dengan penulis dan gagal jika tidak sama.

\subsection{Pengukuran Kinerja}

Dalam pengukuran kinerja kualitas sistem dihitung dan digunakan nilai-nilai False Rejection Rate (FRR), False Acceptance Rate (FAR), Equal Error Rate (EER) yang terkait dengan verifikasi dan identifikasi (Pourshahabi et al., 2009) (Sigari et al., 2011). False Rejection Rate (FRR) atau Type I Error yaitu tingkat kesalahan penolakan terhadap data yang seharusnya dikenali (Woodward et al., 2003). Dalam hal ini sistem gagal mengenali tanda tangan asli dan menganggapnya sebagai tanda tangan palsu. Sebagai contoh, jika FRR adalah 0.05\% dari 200 citra tanda tangan asli yang diujikan, maka hal ini berarti bahwa pada tingkat tersebut, satu dari 200 tandatangan asli akan dikenali sebagai tanda tangan palsu. False Acceptance Rate (FAR) atau False Match Rate atau Type II Error adalah tingkat kesalahan penerimaan terhadap data yang seharusnya ditolak karena belum terdaftar. Dalam penerapannya FAR dapat berupa pengenalan tanda tangan palsu sebagai tanda tangan yang asli. FAR dan FRR dapat dihitung dengan menggunakan persamaan (7) dan (8) (Woodward et al., 2003).

$$
\begin{aligned}
& \% F A R=\frac{F A}{N} \\
& \% F R R=\frac{F R}{N}
\end{aligned}
$$

Di mana:

FA adalah jumlah kejadian salah penerimaan.

FR adalah jumlah kejadian salah penolakan, dan $\mathrm{N}$ adalah jumlah data sampel.

Pengujian FAR dilakukan dengan memberikan sejumlah tanda tangan palsu atau tiruan ke dalam sistem. Setiap tanda tangan palsu yang diverifikasi sebagai tanda tangan asli akan meningkatkan nilai FAR. Sedangkan pengujian FRR dilakukan dengan memberikan sejumlah tanda tangan asli ke dalam sistem. Dalam pengujian FRR setiap tanda tangan asli yang ditolak atau diverifikasi sebagai tanda tangan palsu akan meningkatkan nilai FRR.

\section{HASIL DAN PEMBAHASAN}

Pengujian ini dititikberatkan pada penggalian informasi mengenai seberapa jauh akurasi sistem verifikasi tanda tangan dipengaruhi oleh penggunaan ciri HOG dan HoC. Dalam penerapannya, kedua jenis ciri histogram ini dapat dihitung atau diakumulasi dengan 2 cara yaitu pada seluruh area citra atau pada luasan tertentu dari citra. Histogram yang didapatkan dengan cara pertama sering disebut sebagai histogram global. Sedangkan histogram yang didapatkan dengan cara kedua disebut 
histogram lokal. Guna mewakili histogram lokal dan global maka ukuran sel dipilih dengan beberapa variasi. Dengan ukuran citra 240 x 240 piksel maka dipilih variasi ukuran sel pembagi citra antara lain: 15 x 15 piksel, 24 x 24 piksel, $30 \times 30$ piksel, $60 \times$ 60 piksel, dan 120 x 120 piksel. Dan ukuran sel terbesar yang merupakan histogram global adalah $240 \times 240$ piksel.

\subsection{Pengujian FRR}

Nilai \%FRR diuji dengan memberikan citra uji berupa citra tanda tangan asli. Jika sumber data berupa basis data GPDS960Signature maka Citra yang dimaksud adalah 10 citra yang tidak digunakan sebagai citra pembelajaran, lebih rinci, adalah 10 citra terakhir dari 24 citra asli yang disediakan oleh masing-masing klas/orang. Dengan jumlah klas sebanyak 500 maka jumlah keseluruhan citra yang digunakan dalam pengujian nilai \%FRR adalah 500 x $24=12.000$ citra. Bila sumber data adalah basis data FUM-PHSDB maka dari 20 citra asli (genuine) yang disediakan dalam tiap kelas (signer) digunakan 10 citra sebagai citra pelatihan dan sisanya, 10 citra, digunakan sebagai citra uji. Variasi jumlah citra latih per orang hanya menggunakan 5 dan 10 citra latih. Rekapitulasi dari hasil perhitungan nilai \%FRR ditampilkan dalam Tabel 1. Grafik hasil perhitungan \%FRR ditunjukkan dalam Gambar 5 dan Gambar 6.

Tabel 1. Hasil rekapitulasi perhitungan nilai \%FRR

\begin{tabular}{cccccc}
\hline \multirow{2}{*}{$\begin{array}{c}\text { Ukuran } \\
\text { Sel }\end{array}$} & \multicolumn{4}{c}{ GPDS960Signature } & \multicolumn{3}{c}{ FUM-PHSDB } \\
\cline { 2 - 6 } & $\mathbf{4 5}$ & $\mathbf{\# 1 0}$ & $\mathbf{\# 1 4}$ & $\mathbf{\# 5}$ & $\mathbf{\# 1 0}$ \\
\hline 15 & 51.92 & 37.04 & 28.52 & 21.5 & 12.0 \\
24 & 48.68 & 35.26 & 27.50 & 18.5 & 7.5 \\
30 & 49.16 & 35.30 & 26.90 & 16.5 & 5.5 \\
60 & 61.30 & 48.44 & 39.28 & 11.5 & 4.0 \\
120 & 76.62 & 67.72 & 58.38 & 20.0 & 16.0 \\
240 & 89.26 & 86.30 & 82.98 & 55.5 & 45.0 \\
\hline
\end{tabular}

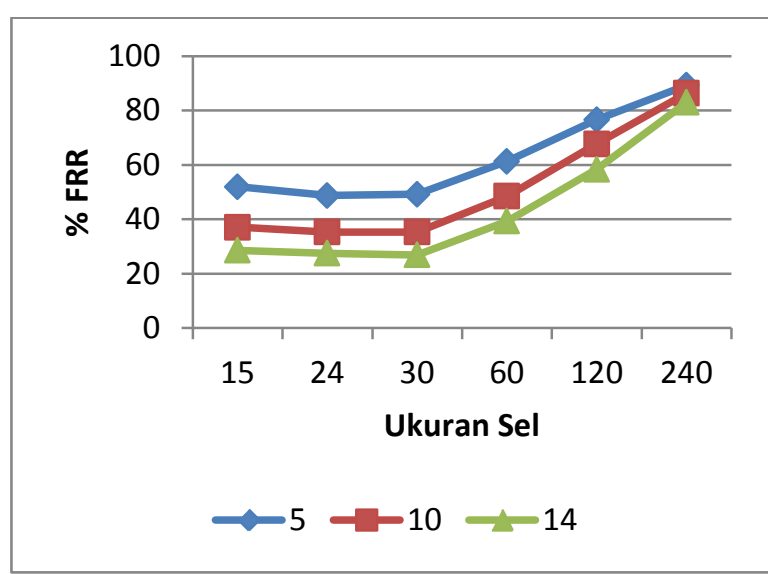

Gambar 5. Grafik nilai \%FRR yang diperoleh dari pengujian dengan basis data GPDS960Signature Corpus
Kedua grafik perbandingan nilai \%FRR juga menunjukkan hal yang selaras dengan pernyataan yang diungkapkan oleh penelitian Dalal di tahun 2005 maupun Laptev di tahun 2009. Dinyatakan bahwa cakupan daerah perhitungan histogram memberikan dampak yang besar bagi pengenalan obyek (Laptev, 2009). Histogram global tidak cocok untuk citra yang kompleks, pendekatan yang lebih baik adalah menggunakan histogram lokal karena memberikan informasi obyek yang lebih spesifik (Dalal \& Triggs, 2005). Dalam kedua grafik, baik dalam kasus GPDS960Signature dan FUM-PHSDB, menunjukkan bahwa nilai \%FRR yang didapatkan dari ukuran sel lokal (15, 24, 30, 60, dan 120) senantiasa memiliki nilai yang lebih rendah bila dibandingkan \%FRR yang didapatkan dari ukuran sel global ( $240 \times 240$ piksel). Artinya bahwa ciri histogram, HOG dan HoC, yang dihitung secara lokal mampu membedakan citra tanda tangan dari masing-masing penandatangan dengan lebih baik bila ciri histogram tersebut diambil secara global.

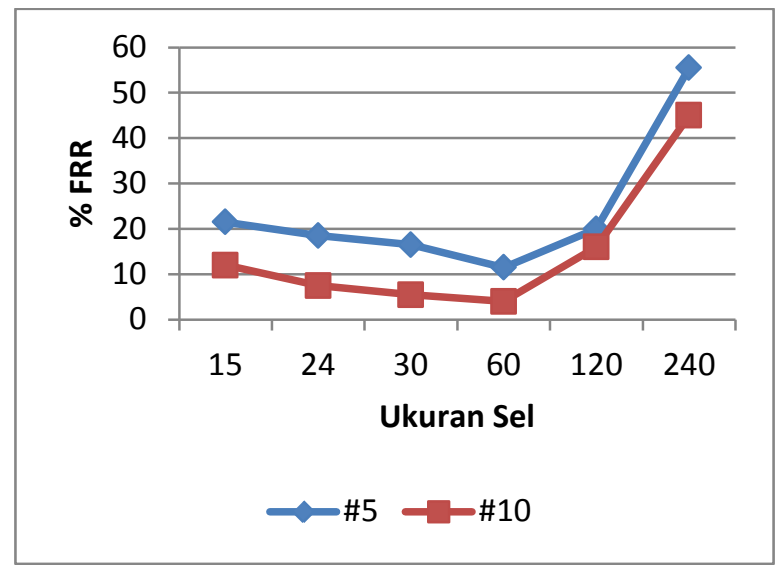

Gambar 6. Grafik nilai \%FRR yang diperoleh dari pengujian dengan basis data FUM-PHSDB

Dari ukuran sel yang bersifat lokal di mana ciri histogram dihitung perlu ditentukan ukuran sel dimana memberikan nilai \%FRR terbaik bagi proses verifikasi. Dalam kasus pengujian basisdata GPDS960Signature ciri histogram yang diambil pada ukuran sel 30 x 30 piksel mampu memberikan nilai \%FRR terkecil yaitu sebesar 26,90. Pengujian dengan menggunakan sumber data dari basis data FUM-PHSDB, menunjukkan nilai \%FRR terbaik pada ukuran 60 x 60 piksel, yaitu sebesar 4 . Kedua nilai \%FRR terbaik tersebut dicapai dengan menggunakan jumlah citra latih per orang sebesar 14 citra untuk basis data uji GPDS960Signature dan 10 citra untuk basis data uji FUM-PHSDB.

Sebagai bahan perbandingan kinerja metoda yang diajukan peneliti digunakan rujukan beberapa penelitian tentang verifikasi tanda tangan dengan metoda ekstraksi ciri lain yang menggunakan basis data FUM-PHSDB. Metoda Local Radon Transform untuk verifikasi tanda tangan offline mendapatkan nilai \%FRR terbaik sebesar 10,5 (Kiani et al., 2009). Metoda 
transformasi countourlet mendapatkan nilai \%FRR terbaik sebesar 12,5 (Pourshahabi et al., 2009). Dan nilai \%FRR terbaik sebesar 15 didapatkan pada saat digunakan metoda Multi Resolutin Gabor Wavelet (Sigari et al., 2011). Sedangkan pada penelitian ini didapatkan hasil \%FRR yang lebih kecil yaitu $4 \%$. Rincian nilai-nilai ini dituliskan dalam Tabel 2.

Tabel 2. Perbandingan nilai \%FRR yang dicapai dalam beberapa penelitian dengan basis data tanda tangan FUM-PHSDB

\begin{tabular}{cc}
\hline Penelitian & \%FRR \\
\hline (Kiani et al., 2009) & 10,5 \\
(Pourshahabi et al., 2009) & 12,5 \\
(Sigari et al., 2011) & 15,0 \\
Peneliti & 4.0 \\
\hline
\end{tabular}

\subsection{Pengujian FAR}

Nilai \%FAR diuji dengan memberikan citra uji berupa citra tanda tangan tiruan. Dalam pengujian dengan sumber data GPDS Corpus, citra tersebut dipilih dari 10 citra pertama dari 30 citra tanda tangan tiruan yang disediakan dalam masing-masing klas. Jumlah keseluruhan citra tanda tangan tiruan yang digunakan dalam pengujian \%FAR adalah 500 $\mathrm{x} 10=5000$ citra. Sedangkan pada pengujian dengan sumber data FUM-PHSDB disediakan 10 citra uji palsu. Rekapitulasi dari hasil perhitungan nilai \%FRR ditampilkan dalam Tabel 3. Grafik hasil perhitungan \%FRR ditunjukkan dalam Gambar 7 dan Gambar 8.

Tabel 3. Hasil rekapitulasi perhitungan nilai \%FAR

\begin{tabular}{cccccc}
\hline \multirow{2}{*}{$\begin{array}{c}\text { Ukuran } \\
\text { Sel }\end{array}$} & \multicolumn{3}{c}{ GPDS960Signature } & \multicolumn{3}{c}{$\begin{array}{c}\text { FUM- } \\
\text { PHSDB }\end{array}$} \\
\cline { 2 - 6 } & \multicolumn{4}{c}{$\sum$ Citra Training / orang } \\
\cline { 2 - 6 } & \#5 & \#10 & \#14 & \#5 & $\# \mathbf{1 0}$ \\
\hline 15 & 27.56 & 34.64 & 36.78 & 43.0 & 52.0 \\
24 & 29.74 & 35.36 & 37.72 & 47.0 & 54.5 \\
30 & 28.80 & 35.58 & 37.56 & 45.5 & 56.5 \\
60 & 22.26 & 27.82 & 29.80 & 46.0 & 57.0 \\
120 & 13.44 & 15.76 & 18.22 & 38.5 & 40.5 \\
240 & 5.76 & 6.04 & 5.94 & 22.5 & 23.5 \\
\hline
\end{tabular}

Hasil yang didapatkan dari pengujian \%FAR berbanding terbalik dengan hasil pengujian \%FRR. Jika pada uji nilai \%FRR pertambahan data latih meningkatkan akurasi sistem untuk mengenali tanda tangan asli, maka pada uji nilai \%FAR pertambahan citra latih meningkatkan kesalahan penerimaan tanda tangan yang mestinya ditolak (tanda tangan palsu). Hal ini nampak pada meningkatnya nilai FAR saat terjadi penambahan jumlah citra latih per orang, seperti yang ditunjukkan oleh grafik dalam Gambar 7. Tingkat kesalahan penerimaan (\%FAR) terkecil didapatkan saat digunakan data latih 5 dan ukuran sel adalah $240 \times 240$ piksel. Nilai \%FAR tersebut sebesar 5,76 .
Kondisi hasil pengujian FAR yang berbalik dengan hasil pengujian FRR ini juga selaras dengan yang disampaikan oleh Sigari dkk. Sistem yang ideal sebenarnya memiliki nilai FRR dan FAR yang sama-sama kecil, namun sistem yang ada tidaklah demikian. Memperkecil nilai FRR akan memperbesar nilai FAR (Sigari et al., 2011). Dalam grafik hasil pengujian FRR dan FAR, Gambar 5 dan Gambar 7, nampak bahwa saat didapatkan nilai FRR mengecil, nilai FAR akan cenderung meningkat.

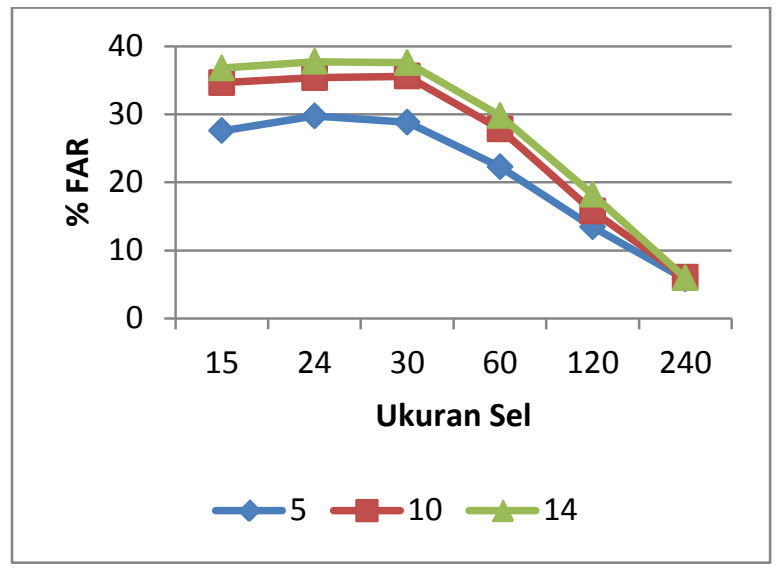

Gambar 7. Grafik nilai \%FAR yang diperoleh dari pengujian dengan basis data GPDS960Signature Corpus

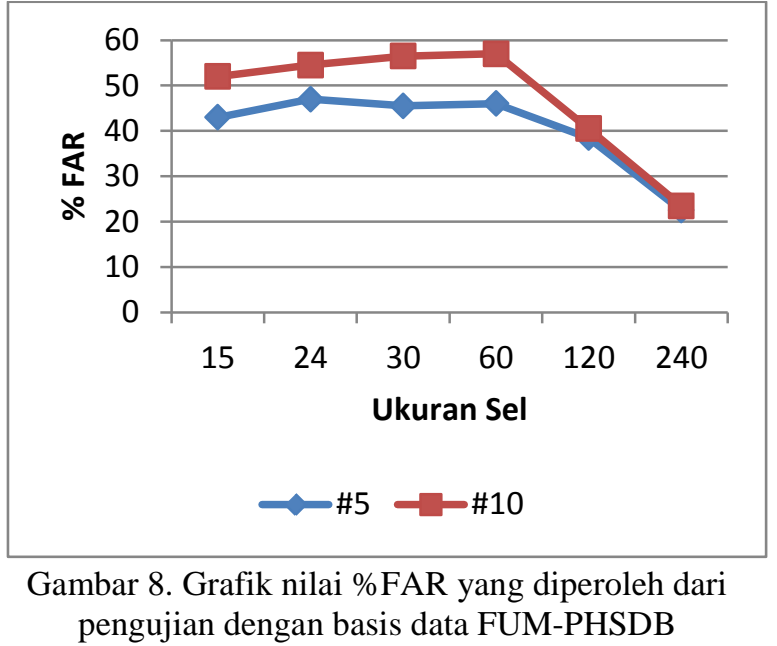

Penentuan nilai FAR terpilih dapat mengacu pada ukuran sel di mana nilai FRR terbaik dicapai. Untuk sumber data pengujian adalah GPDS960Signature ditentukan nilai \%FAR sebesar 37,56. Dan untuk sumber data pengujian adalah FUM-PHSDB ditentukan nilai \%FAR sebesar 57.

\section{KESIMPULAN}

Dari pengujian yang dilakukan maka dapat ditarik beberapa kesimpulan antara lain:

1. Kombinasi ciri Histogram of Oriented Gradient (HOG) dan Histogram of Curvature (HoC) dapat digunakan untuk melakukan proses verifikasi tanda tangan secara offline. 
2. Cakupan area citra (ukuran sel) di mana HOG dan HoC dihitung sangat menentukan kinerja sistem verifikasi. Histogram HOG dan HoC yang dihasilkan pada sebagian area tertentu pada citra disebut histogram lokal dan jika perhitungan dilakukan pada keseluruhan luasan citra disebut histogram lokal.

3. Histogram lokal mampu memberikan nilai kinerja yang baik dalam hal melakukan verifikasi tanda tangan asli bila dibandingkan histogram global.

4. Dari beberapa kombinasi jumlah data latih per orang yang diujicobakan, yaitu 5, 10 dan 14, bahwa jumlah data latih 14 (sumber data GPDS960Signature) dan 10 citra per orang (dengan sumber data FUM-PHSDB) memberikan nilai kesalahan penolakan (\%FRR) terkecil untuk data terverifikasi berupa citra tanda tangan asli.

5. Didapatkan bahwa ukuran sel kurang dari $240 \mathrm{x}$ 240 (ukuran citra) senantiasa memberikan \%FRR yang lebih rendah bila dibandingkan ukuran sel sebesar ukuran citra (240 x 240 piksel).

6. nilai optimal ukuran sel sangat tergantung sumber data yang digunakan. Dalam kasus pengujian basisdata GPDS960Signature ciri histogram yang diambil pada ukuran sel 30 x 30 piksel mampu memberikan nilai \%FRR terkecil yaitu sebesar 26,90. Pengujian dengan menggunakan sumber data dari basis data FUMPHSDB, menunjukkan nilai \%FRR terbaik pada ukuran 60 x 60 piksel, yaitu sebesar 4 .

7. Untuk kasus pengujian dengan sumber data FUM-PHSDB, nilai \%FRR terbaik, yaitu 4, yang diperoleh menunjukkan hasil yang lebih baik bila dibandingkan penelitian dengan menggunakan sumber data yang sama: 10,5 (Kiani et al., 2009), 12,5 (Pourshahabi et al., 2009), 15 (Sigari et al., 2011).

8. Hasil berbeda didapatkan pada pengujian \%FAR yang dilakukan dengan penggunaan citra uji berupa citra tanda tangan tiruan.

9. Histogram HOG dan HoC yang dihitung pada cakupan area citra global bekerja dengan baik dalam menolak citra tanda tangan palsu.

10. Nilai \%FAR terkecil didapatkan pada saat digunakan HOG dan HoC yang dihitung pada ukuran sel 240 x 240 piksel baik dalam pengujian dengan sumber data GPDS960Signature maupun FUM-PHSDB.

11. Hal ini disebabkan karena perbedaan kecil yang mampu dilakukan peniru tanda tangan terlatih (skilled forgery) tidak nampak pada histogram HOG dan HoC yang dihitung secara lokal.

\section{Saran}

Berdasarkan kesimpulan yang ada maka perlu dilakukan kerja lanjutan (future work) yang dapat dilakukan untuk menggali lebih jauh potensi pengembangan penggunaan ciri HOG dan HoC yaitu:

1. Masih perlu dilakukan pengembangan kombinasi dan rekayasa area cakupan perhitungan histogram HOG dan HoC dilakukan sehingga didapatkan histogram yang mampu memperkecil kesalahan penerimaan terhadap tangan tiruan yang terlatih (skilled forgery)

2. Masih mungkin untuk dilakukan kombinasi dengan ciri geometri lain dan metoda klasifikasi lain untuk memperkecil nilai \%FRR dan \%FAR.

\section{DAFTAR PUSTAKA}

Acharya, T. \& Ray, A.K., 2005. Image Processing Principles and Applications. Hoboken, New Jersey: John Wiley \& Sons.

Anon., n.d. FUM-PHSDB: The FUM-Persian Handwritten Signature Database. [Online] Available at: mvlab.um.ac.ir [Accessed 11 October 2014].

Cheriet, M., Kharma, N., Liu, C.-L. \& Suen, C.Y., 2007. Character Recognition Systems - A Guide for Students and Practitioners. New Jersey - USA: Wiley Interscience - John Wiley \& Sons Publication.

Dalal, N. \& Triggs, B., 2005. Histograms of oriented gradients for human detection. In Conference on Computer Vision and Pattern Recognition (CVPR). San Diego, CA, USA, 2005. IEEE Computer Society.

Ferrer, M.A., Vargas, F., Morales, A. \& Ordonez, A., 2012. Robustness of Offline Signature Verification based on Grey Level Features. IEEE Transaction on Forensic and Security, June. pp.977-77.

Fujisawa, Y., Shi, M., Wakabayashi, T. \& Kimura, F., 2000. Handwritten Numeral Recognition Using Gradient and Curvature of Grayscale Image. Pattern Recognition, pp.2051-59.

Gonzales, R.C. \& Woods, R.E., 2008. Digital Image Processing Third Edition. New Jersey: Pearson Education Inc.

Ismail, I.A., Ramadhan, M.A., El Danf, T. \& Samak, A.H., 2008. Automatic Signature Recognition and Verification Using Principal Component Analysis. In Fifth International Conference on Computer Graphics, Imaging and Visualization., 2008. IEEE Computer Society.

Kiani, V., Pourreza, R. \& Pourreza, H.R., 2009. Offline Signature Verification Using Local Radon Transform and Support Vector Machines". International Journal of Image Processing, 3(5), pp.184 - 194. 
Kobayashi, T., Hidaka, A. \& Kurita, T., 2008. Selection of Histograms of Oriented Gradients Features for Pedestrian Detection. In ICONIP 2007. Berlin Heidelberg, 2008. Springer-Verlag.

Laptev, I., 2009. Improvements of Object Detection Using Boosted Histograms. Image and Vision Computing, XXVII(5), pp.535-44.

Narappanawar, N.L., Kumar, S., Dhameliya, N.L. \& Joshi, M., 2011. Skew Detection and Correction in Signature Verification System. In A National Conference on Machine Vision and Image Processing MVIP 2011. Pune, India, 2011. Department of Electronics and Telecommunication, College of Engineering, Pune.

Nguyen, V. \& Blumenstein, M., 2011. An Application of the 2D Gaussian Filter for Enhancing Feature Extraction in Off-line Signature Verification. In 2011 International Conference on Document Analysis and Recognition., 2011. IEEE Computer Society.

Nguyen, V. et al., 2010. Performance Analysis of the Gradien Feature and Modified Direction Feature for Off-line Signature Verification. In 2010 12th International Conference of Frontier in Handwriting Recognition., 2010. IEEE Computer Society.

Nixon, M.S. \& Aguado, A.S., 2002. Feature Extraction and Image Processing. Oxford: Newnes - A member of the Reed Elsevier plc group.

Parodi, M., Gomez, C.J. \& Belaid, A., 2011. A Circular Grid-Based Rotation Invariant Feature Extraction Approach for Off-line Signature Verification. In 2011 International Conference on Document Analysis and Recognition., 2011. IEEE Computer Society.

Pourshahabi, M.R., Sigari, M.H. \& Pourreza, H.R., 2009. Offline Handwritten Signature Identification and Verification Using Contourlet. In 2009 International Conference of Soft Computing and Pattern Recognition. California, 2009. IEEE Computer Society.

Sigari, M.H., Pourshahabi, M. \& Pourreza, H., 2011. Offline Handwritten Signature Identification and Verification Using MultiResolution Gabor Wa. International Journal of Biometrics and Bioinformatics (IJBB), 5(4), pp.234-48.

Sonka, M., Hlavac, V. \& Boyle, R., 2008. Image Processing, Analysis, and Machine Vision. Ontario, USA: Thomson Learning.

Vargas, J.F. \& Ferrer, M.A., 2011. Texture Analysis for Off-Line Signature Verification. In Z.
Riaz, ed. Biometric Systems, Design and Applications. Janeza Trdine 9, 51000 Rijeka, Croatia: InTech Open. pp.119-234.

Wibowo, A.M., 2001. Naskah Akademik RUU Transaksi Elektronik dan Tanda Tangan Elektronik. Laporan Penelitian Tahap Pertama. Jakarta: Republik Indonesia Deperindag \& Lembaga Kajian Hukum Teknologi Fakultas Hukum UI.

Woodward, J.D., Orlans, N.M. \& Higgins, P.T., 2003. Biometrics. New York: The McGraw-Hill Companies. 